\title{
Diaré kan behandles med feces
}

\author{
Feces fra frisk donor kan gi gode \\ resultater ved Clostridium difficile- \\ assosiert diaré.
}

Clostridium difficile er en hyppig årsak til sykehusdiaré. Vanligvis er diaré forårsaket av denne bakterien mild og kortvarig, men i enkelte tilfeller kan det være alvorlig. Residiv etter behandling er ikke uvanlig $(20 \%)$. I slike tilfeller kan fecesterapi forsøkes. Det antas at slik avføringstransplantasjon reetablerer normal mikroflora i tykktarmen. Behandlingen har vanligvis god effekt og ingen bivirkninger - og tiltaket er enkelt og billig.

I en ny studie fra USA har man undersøkt tarmfloraen til en pasient som led av residiverende Clostridium difficile-assosiert diaré (1). Hun fikk overført feces fra sin friske ektefelle. 14 dager etter transplantasjonen var bakteriesammensetningen nokså lik donorens. Pasienten ble kvitt plagene.

- Resultatet er som forventet, sier professor Arnold Berstad ved Institutt for indremedisin, Universitetet i Bergen. - Vi foretrekker å administrere feces med gastroskop eller sonde i tynntarmen og etterskylle med en polyetylenglykolløsning. Rektal instillasjon er ofte utilstrekkelig, og cøkal administrasjon med koloskop kan være farlig og/eller umulig når tykktarmen er kraftig betent, sier han.

- En persons tarmflora er vanskelig å endre. Men når den først er brutt ned av $\mathrm{C}$. difficile, er det tydeligvis mulig. Vanlige kommersielle probiotika inneholder laktobasiller og/eller bifidobakter. De overførte bakteriene kan gjenfinnes i tarmen de første dagene etter inntak, men de evner ikke å etablere seg der. Ved fekal transplantasjon overføres en hel biofilm, dvs. en mengde forskjellige bakterier, kanskje over 1000 arter, som samarbeider. Å lage noe tilsvarende in vitro er ønskelig. De estetiske og etiske problemer ved fekal transplantasjon kunne da reduseres, og effekten av endret colonflora ved andre tilstander, f.eks. irritabel tarm og fedme, kunne lettere utforskes, sier Berstad.

\section{Erlend Hem}

erlend.hem@medisin.uio.no

Tidsskriftet

\section{Litteratur}

1. Khoruts A, Dicksved J, Jansson JK et al. Changes in the composition of the human fecal microbiome after bacteriotherapy for recurrent Clostridium difficile-associated diarrhea. J Clin Gastroenterol 2010; 44: 354-60.

\section{Overvekt hos mor og prematuritet}

Det er en utbredt oppfatning at overvekt hos mor gir redusert risiko for lav fødselsvekt hos barnet. Kanadiske og kinesiske forskere har nå undersøkt sammenhengen mellom overvekt hos mor og for tidlig fødsel og lav fødselsvekt (BMJ 2010; 341: c3428).

Ut fra systematiske oversikter og metaanalyser fant de at de var større risiko for fødsel før 37. uke for kvinner med overvekt og fedme enn for normalvektige. Den gunstige effekten som overvekt og fedme hos kvinnen hadde på lav fødselsvekt (< $2500 \mathrm{~g}$ ) var større i utviklingsland enn i industrialiserte land, men denne effekten forsvant når det ble justert for publikasjonsskjevhet.

\section{Angiotensinreseptorblokkere gir økt risiko for kreft}

Disse midlene brukes bl.a. ved hjerteog karsykdom og diabetesnefropati, men renin-angiotensin-systemet inngår også i reguleringen av celleproliferasjon og tumorprogrediering. Nå viser en ny metaanalyse at det er moderat økt risiko for nydiagnostisert kreft hos dem som behandles med angiotensinreseptorblokkere (Lancet Oncol 2010; 11: 627-36).

Analysen omfattet randomiserte, kontrollerte studier. De pasientene som var randomisert til angiotensinreseptorblokkere hadde signifikant større risiko for nydiagnostisert kreft enn kontrollpersonene $(7,2 \%$ versus $6,0 \%$; RR 1,08$)$, men det var ingen signifikant forskjell i kreftrelatert mortalitet.

\section{Metode ved selvmordsforsøk predikerer prognosen}

\author{
Hvilken metode som brukes ved \\ forsøket, predikerer risikoen for et \\ senere fullbyrdet selvmord. Det viser \\ en langtidsoppfølging fra Sverige.
}

Studien omfattet nesten 50000 personer som ble innlagt i sykehus etter selvmordsforsøk i perioden 1973-82 (1). I oppfølgingsperioden frem til 2003 begikk over $5700(12 \%)$ selvmord.

Risikoen for fullbyrdet selvmord var særlig høy hos dem som hadde forsøkt å begå selvmord ved hengning/kvelning, drukning, utsprang fra høyde eller med skytevåpen. Det var seks ganger vanligere med selvmord etter hengningsforsøk og fire ganger vanligere etter drukningsforsøk sammenliknet med forgiftningsforsøk. Risikoen var spesielt stor det første året $(4,2 \%)$. Det ble ofte brukt samme metode i forsøket som i selve selvmordet. Det gjaldt ikke forgiftning $-39 \%$ av dem som hadde prøvd dette, tok sitt liv på en annen måte. Av dem som hadde forsøkt hengning/ kvelning, var det over halvparten som tok sitt liv i hele perioden. Av dem med psykosediagnose som hadde valgt denne måten, var det $84 \%$ som senere tok sitt liv.

- Disse selvmordsforsøkene fant sted for 30-40 år siden. Oppmerksomheten omkring selvmordsatferd, ikke minst med sikte på faresignaler, og bedre oppfølging har forhåpentlig ført til at dødeligheten er blitt noe mindre. Likevel er dødeligheten etter selv-

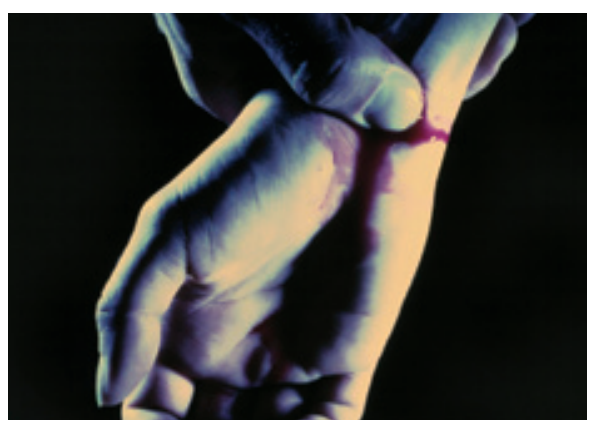

Illustrasjonsfoto. (C) Henrik Sørensen/SCANPIX

mordsforsøk fortsatt betydelig. Det er ennå langt igjen før oppfølgingen er like systematisk som ved somatiske lidelser med tilsvarende risiko, sier overlege Øivind Ekeberg ved Akuttmedisinsk avdeling, Oslo universitetssykehus, Ullevål.

- Studien bekrefter den kliniske erfaring at selvmordsforsøk med voldsomme metoder innebærer høyere risiko for senere selvmord. I tillegg har mange som overlever slike forsøk, oftere alvorlige somatiske senfølger. Det finnes få andre studier av denne gruppen pasienter, sier Ekeberg.

\section{Erlend Hem}

erlend.hem@medisin.uio.no

Tidsskriftet

\section{Litteratur}

. Runeson B, Tidemalm D, Dahlin M et al. Method of attempted suicide as predictor of subsequent successful suicide: national long term cohort study. BMJ 2010; 341: c3064. 